\title{
CLOVE-SEED SIZE AND HEALTH AND PLANT SPACING ON THE VIABILITY OF GARLIC CROPS ${ }^{1}$
}

\author{
MAYKY FRANCLEY PEREIRA DE LIMA ${ }^{2 *}$, WELDER DE ARAÚJO RANGEL LOPES ${ }^{3}$, MARIA ZULEIDE DE \\ NEGREIROS ${ }^{3}$, FRANCISCO VILELA RESENDE ${ }^{3}$, ANTÔNIA TAMIRES MONTEIRO BESSA ${ }^{3}$, LEILSON COSTA \\ GRANGEIRO $^{3}$
}

\begin{abstract}
Garlic is a vegetable that has a high economic importance for Brazil. However, despite increases in garlic bulb production in the last years, Brazil is still dependent on imported garlic to meet the national demand. Thus, proper management practices and the use of virus-free clove-seeds are promising alternatives to ensure a high productivity and profitability. Thus, the objective of this work was to evaluate production characteristics and profitability of conventional and virus-free garlic crops as a function of different clove-seed sizes and plant spacings. Two experiments were conducted simultaneously, using virus-free and conventional garlic plants in Portalegre, state of Rio Grande do Norte, Brazil, in a randomized block experimental design, with four replications. The treatments were arranged in split-plot, with the clove-seed size (large and small) in the plots, and the spacing between plants $(7.5,10.0,12.5$, and $15.0 \mathrm{~cm})$ in the subplots. The combination between the use of virus-free clove-seeds, large clove-seed size, and spacing of $12.5 \mathrm{~cm}$ between plants resulted in the highest commercial bulb yield and net income, R\$ (BRL) 85,151.00 ha ${ }^{-1}$. The use of large clove-seeds and spacing of $7.5 \mathrm{~cm}$ between plants are recommended for conventional garlic crops.
\end{abstract}

Keywords: Allium sativum L. Profitability. Density of planting.

\section{VIABILIDADE DO CULTIVO DE ALHO EM FUNÇÃO DA SANIDADE, TAMANHO DO BULBILHO E ESPAÇAMENTO}

\begin{abstract}
RESUMO - O alho é uma hortaliça de grande importância econômica para o Brasil. No entanto, apesar da produtividade do alho brasileiro ter aumentado nos últimos anos, ainda há uma dependência do alho importado para atender a demanda interna. Dessa forma, práticas de manejo e o uso de alho-semente livre de vírus, tornam -se uma alternativa promissora para garantir maiores produtividades e rentabilidade. Assim, o objetivo deste trabalho foi avaliar características de produção e rentabilidade do cultivo de alho convencional e livre de vírus em função do tamanho de bulbilho-semente e espaçamento entre plantas. Dois experimentos foram conduzidos simultaneamente, utilizando alho livre de vírus e convencional, em Portalegre-RN. O delineamento experimental foi o de blocos casualizados, com quatro repetições. Os tratamentos foram dispostos em parcelas subdivididas, sendo as parcelas representadas pelo tamanho dos bulbilhos: grande e pequenos. As subparcelas foram compostas por quatro espaçamentos entre plantas: 7,5; 10,0;12,5 e 15,0 cm. A combinação entre o alhosemente livre de vírus, bulbilho de tamanho grande e espaçamento de $12,5 \mathrm{~cm}$ entre plantas resultou em maior produtividade comercial e receita líquida $\left(\mathrm{R} \$ 85.151,00 \mathrm{ha}^{-1}\right)$. Para o alho convencional, sugere-se a utilização de bulbilhos grandes com espaçamento de $7,5 \mathrm{~cm}$ entre plantas.
\end{abstract}

Palavras-chave: Allium sativum L. Rentabilidade. Densidade de plantio.

\footnotetext{
${ }^{*}$ Corresponding author

${ }^{1}$ Received for publication in 08/05/2020; accepted in 02/17/2021.

Paper extracted from the doctoral thesis of the first author.

${ }^{2}$ SESI - Serviço Social da Indústria, Mossoró, RN, Brazil; maykylima@bol.com.br - ORCID: 0000-0002-4405-7354

${ }^{3}$ Department of plant sciences, Universidade Federal Rural do Semi-Árido, Mossoró, RN, Brazil; welder.lopes@hotmail.com - ORCID: 0000-0002-9380-6710, zuleide@ufersa.edu.br - ORCID: 0000-0002-0665-326X, francisco.resende@embrapa.br - ORCID: 0000-00026354-4828, tami.bessa@hotmail.com - ORCID: 0000-0002-8068-9068, leilson@ufersa.edu.br - ORCID: 0000-0002-4613-3605.
} 


\section{INTRODUCTION}

Garlic (Allium sativum L.) is a vegetable that has high economic importance in Brazil. The current mean national garlic bulb yield is $11.61 \mathrm{Mg} \mathrm{ha}^{-1}$. However, despite improvements in the last years, the Brazilian garlic production is still insufficient to supply the domestic market demand, which are met by imports from other countries, mainly China, Argentina, and Spain (IBGE, 2017). However, the addition of new technologies, such as the use of improved cultivars, vernalization, and mainly the adoption of virus-free clove-seeds has significantly increased the bulb yield and quality of garlic plants in Brazil, and the crop expansion to other regions of the country (SOUZA et al., 2011).

The use of virus-free clove-seeds has become a technological advance for the development of the garlic production chain in Brazil. It made possible the exploration of the maximum productive potential of the plants due to the eradication of viruses that are found in conventional (infected) seeds, and the obtaining more vigorous and productive plants (LUÍS et al., 2020). According to Resende et al. (1999), the use of plants from virus-free garlic seeds can increase the garlic bulb yield in up to $100 \%$ when compared to the use of conventional seeds.

Virus-free garlic seeds are obtained by a clonal cleaning, through the growing of stem apexes focused on recovering the health of garlic clones infected by viruses. Apical meristem cells, basal discs, and root ends are grown in vitro to reproduce new virus-free plants (MENEZES JÚNIOR, 2011); therefore, their seeds have higher prices than conventional ones.

In addition, the use of proper spacing between plants and clove-seed size are also crop management strategies that contribute to increase garlic bulb yield and profitability, and make the garlic Brazilian market more competitive. Plant spacing is an important factor for garlic crops, which affects the growth and development of plants. Changes in plant spacing affect the interception of light by leaves and the root water and nutrient absorptions, which affect the garlic bulb yield and size (MORAVČEVIĆ et al., 2011).

The use of short spacings between plants provides, in general, higher bulb production per area, but smaller bulb sizes (VIDYA, 2015). Contrastingly, large spacings result in larger bulbs and better commercial classification, due to the higher soil area for each plant and lowest competition (MUNEER et al., 2017), which generates a higher final garlic bulb yield and profitability.

The clove-seed size used is also important for the final garlic bulb yield (LIMA et al., 2019); the use of large clove-seeds result in higher bulb yields due to the higher vegetative growth caused by the higher quantity of nutritional reserves in the seeds (MAHADEEN, 2011).

The clove-seed size or weight to be used is defined base on the density of plants. Therefore, establishing an optimal population and clove-seed size is essential to maximize the exploration of production factors and ensure high bulb yields and profitability. Thus, the objective of this work was to evaluate production characteristics and profitability of conventional and virus-free vernalized garlic crops as a function of different clove-seed sizes and plant spacings.

\section{MATERIAL AND METHODS}

The study consisted of two experiments, one with virus-free garlic crops and other with conventional garlic crops, using seeds obtained from the Brazilian Agricultural Research Corporation (EMBRAPA). The experiments were conducted simultaneously from May to September 2017, in an experimental area in Portalegre, state of Rio Grande do Norte, Brazil $\left(6^{\circ} 1^{\prime} 20^{\prime \prime} \mathrm{S}, 38^{\circ} 1^{\prime} 45^{\prime \prime} \mathrm{W}\right.$, and $520 \mathrm{~m}$ of altitude). The region has an Aw, tropical rainy climate, according to the Köppen classification, with a dry winter and a rainy season up to July. The climatic data in the area were monitored during the experiment and showed minimum temperatures between 15 and $21^{\circ} \mathrm{C}$, mean temperature of $24.7^{\circ} \mathrm{C}$, maximum temperatures between 26 and $34{ }^{\circ} \mathrm{C}$, and a rainfall depth of $65 \mathrm{~mm}$.

The soil of the experimental area was classified as a Lithic Udorthent, with weak A Horizon and medium texture (EMBRAPA, 2018). The soil chemical analysis showed $\mathrm{pH}\left(\mathrm{H}_{2} \mathrm{O}\right)$ of 4.60 , $4.97 \mathrm{~g} \mathrm{Kg}^{-1}$ of organic matter, $0.07 \mathrm{~g} \mathrm{~kg}^{-1}$ of $\mathrm{N}$, $5.3 \mathrm{mg} \mathrm{dm}^{-3}$ of P, $79.7 \mathrm{mg} \mathrm{dm}^{-3}$ of K, $8.9 \mathrm{mg} \mathrm{dm}^{-3}$ of $\mathrm{Na}, 2.6 \mathrm{cmol}_{\mathrm{c}} \mathrm{dm}^{-3}$ of $\mathrm{Ca}, 1.3 \mathrm{cmol}_{\mathrm{c}} \mathrm{dm}^{-3}$ of $\mathrm{Mg}$, $0.1 \mathrm{cmol}_{\mathrm{c}} \mathrm{dm}^{-3}$ of $\mathrm{Al}$, and $2.31 \mathrm{cmol}_{\mathrm{c}} \mathrm{dm}^{-3}$ of $\mathrm{H}+\mathrm{Al}$.

A randomized block experimental design was used, with four replications. The treatments were arranged in split-plot, with the clove-seed size (large and small) in the plots, and the spacing between plants $(7.5,10.0,12.5$, and $15.0 \mathrm{~cm})$ in the subplots; the spacing between planting rows was fixed in 20 $\mathrm{cm}$, resulting in planting densities of 500.000 , $375.000, \quad 300.000$ and 250.000 plants $\mathrm{ha}^{-1}$, respectively. Large clove-seeds were those retained in the 1 and 2 sieves $(15 \times 25$ and $10 \times 20 \mathrm{~mm}$ meshes, respectively) and small clove-seeds were those retained in the 3 and 4 sieves $(8 \times 17$ and $5 \times 17 \mathrm{~mm}$ meshes, respectively).

The mean weight of the large and small sizes varied from 1.51 to $2.32 \mathrm{~g}$ and from 0.83 to $0.98 \mathrm{~g}$, respectively, for the virus-free clove-seeds, and from 1.87 to $2.61 \mathrm{~g}$ and from 0.91 to $1.28 \mathrm{~g}$, respectively, for the conventional clove-seeds.

The Roxo Pérola de Caçador garlic cultivar 
was used. The subplots consisted of beds of $0.2 \mathrm{~m}$ height, $1.0 \mathrm{~m}$ width, and 1.50, 2.00, 2.50, and $3.00 \mathrm{~m}$ length, respectively for the plant spacings of $20 \times 7.5$ $\mathrm{cm}, 20 \times 10 \mathrm{~cm}, 20 \times 12.5 \mathrm{~cm}$, and $20 \times 15 \mathrm{~cm}$, with five planting rows, totaling 100 plants. The three central rows of each subplot were evaluated, discarding one plant from each end of the rows, resulting in a population of 54 plants.

The clove-seeds were subjected to a vernalization process for 50 days in a cold chamber at $4 \pm 2{ }^{\circ} \mathrm{C}$ and relative humidity of approximately $70 \%$, before planting. The bulbs were withdrawn from the cold chamber at one day before planting for threshing. The cloves were then classified by size and planted according to the treatments adopted.

The soil was prepared using one plowing and one harrowing, and the beds were raised manually. The soil acidity was corrected by when the beds were raised by incorporating $400 \mathrm{~kg} \mathrm{ha}^{-1}$ of $\mathrm{Ca}(\mathrm{OH})_{2}$ to the soil. Soil fertilizers were applied at planting based on the soil chemical analysis, using $30 \mathrm{~kg} \mathrm{ha}^{-1}$ of $\mathrm{N}$ (calcium nitrate), $180 \mathrm{~kg} \mathrm{ha}^{-1}$ of $\mathrm{P}_{2} \mathrm{O}_{5}$ (simple superphosphate), $60 \mathrm{~kg} \mathrm{ha}^{-1}$ of $\mathrm{K}_{2} \mathrm{O}$ (potassium chloride), $15 \mathrm{~kg} \mathrm{ha}^{-1}$ of $\mathrm{Mg}$ (magnesium sulfate), 12 $\mathrm{kg} \mathrm{ha}^{-1}$ of $\mathrm{Zn}$ (zinc sulfate), $1.7 \mathrm{~kg} \mathrm{ha}^{-1}$ of B (boric acid), and $75 \mathrm{Mg} \mathrm{ha}^{-1}$ of Pole Fértil ${ }^{\mathbb{R}}$ (a fertilizer based on bovine and chicken manure). Topdressing was applied at 20 and 50 days after planting (DAP), using 30 and $60 \mathrm{~kg} \mathrm{ha}^{-1}$ of $\mathrm{N}$ (calcium nitrate and urea) respectively.

The plant health protection was done using mancozeb-based products for purple spot, and chlorfenapyr-based products for pests, such as thrips and mites. Weeds were controlled by manual weeding, when necessary.

A micro sprinkler irrigation system was used, with flow of $40 \mathrm{~L} \mathrm{~h}^{-1}$ and pressure of $200 \mathrm{KPa}$. The irrigation was suspended at three days before harvesting, when the plants were at the maturation stage, characterized by yellowing and partial drying of shoots. The plants were harvested manually at $104 \pm 4$ DAP and subjected to a pre-cure process, consisted of keeping them exposed to the Sun for three days, and a shade cure, consisted of keeping them in a dry and airy place for 17 days. Then, the bulbs were subjected to cleaning.

Plant height $(\mathrm{cm})$ from the ground level to the end of the longest leaf was evaluated at 60 DAP in ten plants of the area useful. Mean bulb weight $(\mathrm{g})$, total bulb yield $\left(\mathrm{Mg} \mathrm{ha}^{-1}\right)$, and commercial bulb yield $\left(\mathrm{Mg} \mathrm{ha}^{-1}\right)$ were evaluated after the cure process. The commercial bulb yield is the yield of bulbs of commercial classes, those with transversal diameter above $32 \mathrm{~mm}$ and not sprouted, according to the Ordinance no. 242 of September 17, 1992 of the Brazilian Ministry of Agriculture, Livestock, and Supply (MAPA).

The economic analysis included calculations of production costs, as proposed by Martin et al.
(1998). The nominal prices of all inputs were assessed from May to November 2017; the input prices and the machinery operational costs were obtained in the region of Portalegre and Mossoró, state of Rio Grande do Norte, Brazil. The labor cost was calculated based on the Breazilian minimum wage, R\$ (BRL) 937.00 plus social charges equivalent to $10 \%$ of the minimum wage, resulting in a cost of R\$ (BRL) 5.15 per working hour.

The profitability was determined for each treatment by calculating the total operational cost in $\mathrm{R} \$(\mathrm{BRL}) \mathrm{ha}^{-1}$ obtained by the sum of all production costs and the gross income in $\mathrm{R} \$(\mathrm{BRL}) \mathrm{ha}^{-1}$ resulted from the selling of the production, according to the bulb class. The garlic prices used were those practiced at the month of harvest by the Rio Grande do Norte State Food Supply Center, according to each class. The net income in $\mathrm{R} \$(\mathrm{BRL}) \mathrm{ha}^{-1}$ was obtained through the difference between the gross income and total operational cost.

The data were subjected to joint analyses of variance; the means of the variables affected by the clove-seed size and health were compared by the $\mathrm{t}$ test $(p \leq 0.05)$, and those affected by the spacing between plants were compared by regressions analyses, by the $\mathrm{F}$ test $(p \leq 0.05)$

\section{RESULTS AND DISCUSSION}

The effect of the interaction between the spacing between plants, clove-seed health, and clove -seed size was significant for the mean bulb weight, total bulb yield, commercial bulb yield, and gross and net income. The effect of the interaction between the clove-seed size and of clove-seed health was significant for plant height; and the isolate effect of spacing was significant for plant height.

Virus-free garlic plants had higher heights than conventional ones, regardless of the clove-seed size planted, representing an increase of $13.5 \%$ and $20 \%$ for the use of small and large clove-seeds, respectively (Table 1 ).

Virus-free garlic plants had, in general, higher vegetative vigor than those from conventional (infected) seeds. This was found during all crop phenological stages, mainly in the period of higher vegetative growth, as found in other studies (RESENDE; FAQUIN; SOUZA, 2000; RESENDE; GUALBERTO; SOUZA, 2000). A gradual degeneration of garlic plants has been observed as a symptom of viral infections, with a consequent decrease in vegetative vigor (MELO FILHO et al., 2006).

Garlic plants from conventional and virusfree seeds had the highest heights when using large clove-seeds (Table 1). This is the due to the positive effect of a higher quantity of nutrient reserves available in large clove-seeds, which makes the 
plants more vigorous, improving plant growth and development, resulting in the higher heights (MAHADEEN, 2011). This result is consistent with those reported by Lencha and Buke (2017), who found higher heights for garlic plants grown from large clove-seeds $(2.0-2.5 \mathrm{~g})$ when compared to those form small clove-seeds (1.0-1.5 g).

Table 1. Mean height of conventional and virus-free garlic plants grown from different clove-seed sizes.

\begin{tabular}{ccc}
\hline \multirow{3}{*}{ Plant health } & \multicolumn{3}{c}{ Plant height $(\mathrm{cm})$} \\
\cline { 2 - 3 } & \multicolumn{3}{c}{ Clove-seed size } \\
\cline { 2 - 3 } & Small & Large \\
\hline Conventional & $51.98 \mathrm{Bb}$ & $54.57 \mathrm{Ab}$ \\
Virus-free & $59.01 \mathrm{Ba}$ & $65.46 \mathrm{Aa}$ \\
\hline
\end{tabular}

Means followed by same uppercase letter in the rows, and lowercase in the columns, are not different by the $t$ Student test $(p \leq 0.05)$.

A mean minimum estimated plant height of $55.4 \mathrm{~cm}$ was found for the spacing of $7.5 \mathrm{~cm}$, which was significantly lower than that found for the spacing of $12.5 \mathrm{~cm}(59.5 \mathrm{~cm})$, with a stabilization trend up to the highest estimated plant height $(59.6 \mathrm{~cm})$ in the spacing of $15 \mathrm{~cm}$ (Figure 1). The higher plant heights in the wider spacings were probably due to the better light, water, and nutrient uses by the plants, which result in a higher photosynthetic activity. Similar results were reported by Muneer et al. (2017), who evaluated growth characteristics of garlic plants grown under different spacings between plants ( 3 to $11 \mathrm{~cm}$ ) and found that less dense spacings result in higher plant heights.

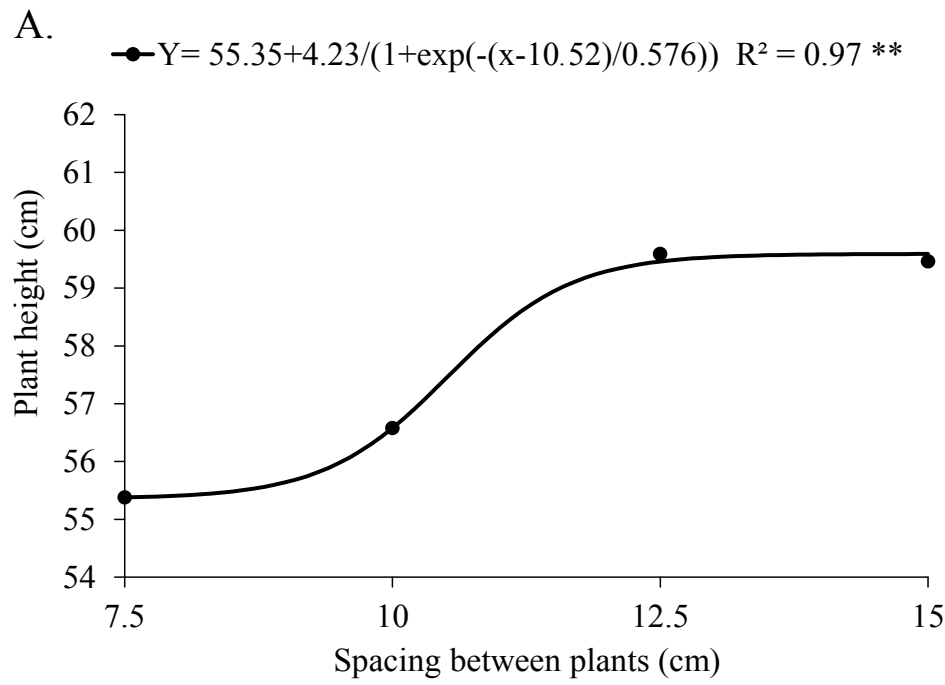

Figure 1. Plant height as a function of spacing between plants.

The mean bulb weight (MBW) of plants from large clove-seeds was higher than that of plants from small clove-seeds, regardless of the plant health status and plant spacing. The MBW of infected and virus-free plants grown from large clove-seeds were $16 \%$ and $29 \%$ higher, respectively, than those of plants grown from small clove-seeds (Table 2).

MBW gains with the use of large clove-seeds have been widely reported in studies and found in commercial crops. This can be explained by the greater carbohydrate and mineral reserves in large clove-seeds, which improves cell division and stretching, resulting in more vigorous plants that present better development and can maintain photosynthetically active leaves for longer times, which contributes to a higher photoassimilate production for the bulbs, than that in plants from small clove-seeds (MAHADEEN, 2011; MARODIN, 2014). Moreover, according to Lencha and Buke (2017), the greater nutritional reserves of large clove-seeds result in a faster establishment of emerging shoots and more efficient use of natural resources in the growth and developmental stages. 
Table 2. Mean bulb weights of conventional and virus-free garlic plants grown from different clove-seed sizes in different spacings between plants.

\begin{tabular}{|c|c|c|c|}
\hline \multicolumn{4}{|c|}{ Mean bulb weight $\left(\right.$ g planta $\left.^{-1}\right)$} \\
\hline \multirow{2}{*}{ Spacing between plants $(\mathrm{cm})$} & \multirow{2}{*}{ Plant health } & \multicolumn{2}{|c|}{ Clove-seed size } \\
\hline & & Small & Large \\
\hline \multirow{2}{*}{7.5} & Conventional & $13.65 \mathrm{Bb}$ & $16.04 \mathrm{Ab}$ \\
\hline & Virus-free & $16.58 \mathrm{Ba}$ & $19.10 \mathrm{Aa}$ \\
\hline \multirow{2}{*}{10} & Conventional & $15.95 \mathrm{Bb}$ & $18.46 \mathrm{Ab}$ \\
\hline & Virus-free & $22.07 \mathrm{Ba}$ & $26.29 \mathrm{Aa}$ \\
\hline \multirow{2}{*}{12.5} & Conventional & $17.76 \mathrm{Bb}$ & $19.53 \mathrm{Ab}$ \\
\hline & Virus-free & $27.94 \mathrm{Ba}$ & $37.77 \mathrm{Aa}$ \\
\hline \multirow{2}{*}{15} & Conventional & $17.13 \mathrm{Bb}$ & $20.94 \mathrm{Ab}$ \\
\hline & Virus-free & $24.59 \mathrm{Ba}$ & $34.84 \mathrm{Aa}$ \\
\hline
\end{tabular}

Means followed by same uppercase letter in the rows comparing clove-seed sizes within each plant health and spacing between plants, and lowercase in the columns comparing plant health within each clove-seed size and spacing between plants, are not different by the t Student test $(p \leq 0.05)$.

This result is in consistent with those reported by Nasir, Regasa and Yirgu (2017), who found an increase of $23 \%$ in $\mathrm{MBW}$ in commercial garlic crops as a response to the increase in clove-seed weight from 1.5-2.5 to 2.6-3.5 g. MBW is an important characteristic for the marketing of garlic and is related to the final bulb yield, since greater bulbs have higher prices in the market.

Considering the plant health within each clove-seed size and plants spacing, virus-free plants grown from small and large clove-seeds had $41 \%$ and $57 \%$ higher MBW than conventional plants, respectively (Table 2 ).

This higher MBW was due to the plant vigor and the vegetative growth measured by the plant height, which result in a greater net photosynthesis. Resende et al. (1999) found that the use of cloveseeds of Gigante Roxão cultivar obtained from tissue culture results in an MBW approximately $109 \%$ higher than the use of conventional clove-seeds, confirming the results found in the present work when using large clove-seeds. Similarly, Resende, Gualberto and Souza (2000) evaluated four garlic cultivars (Gigante Roxão, Gravatá, Lavínia, and Gigante Roxo) and found MBW increases of $16.4 \%$ to $95.9 \%$.

Considering the MBW as a function of spacing between plants, the lowest estimated MBW of virus-free plants grown from large and small clove -seeds (19.1 and $16.58 \mathrm{~g}$, respectively) were found for the spacing of $7.5 \mathrm{~cm}$. The highest estimated MBW of virus-free plants grown from large and small clove-seeds (36.84 and $26.59 \mathrm{~g}$, respectively) was found for the spacing of $15.0 \mathrm{~cm}$ between plants (Figure 2A). Conventional plants also showed higher MBW when using wider spacings, reaching an estimated MBW of $20.4 \mathrm{~g}$ when using large cloveseeds, and $17.65 \mathrm{~g}$ when using small clove-seeds, in the spacing of $15.0 \mathrm{~cm}$ between plants (Figure 2B).
The bulb weights found were, in general, higher in crops with lower populational density, which similarly affected the plant heights (Figure 1A). Increases in number of plants per unit of area increase competition for water, light, and nutrients in the crop environment, resulting lower accumulation of photoassimilates and, consequently, lower biomass accumulation in the garlic bulbs. Muneer et al., (2017) reported that garlic plants grown under low populational densities result in large bulbs due to the high availability of space for shoot growth and development and bulb expansion.

These results are consistent with those found by Marodin (2014), who evaluated virus-free (Chonan cultivar) and conventional garlic plants grown under different spacings $(210,260,300,360$ and $390 \mathrm{~cm}^{2}$ plant $\left.^{-1}\right)$ and found that the wider plant spacing $\left(390 \mathrm{~cm}^{2}\right.$ plant $\left.^{-1}\right)$ resulted in the highest MBW for virus-free $\left(41.6 \mathrm{~g} \mathrm{bulb}^{-1}\right)$ and conventional $\left(26.6 \mathrm{~g} \mathrm{bulb}^{-1}\right)$ plants. Ahmed et al. (2017) used a spacing between rows of $30 \mathrm{~cm}$ to evaluated three spacings between plants $(10,15$, and $20 \mathrm{~cm})$ and found that the spacing of $20 \mathrm{~cm}$ resulted in $33 \%$ higher MBW than the spacing of $10 \mathrm{~cm}$.

The total bulb yield (TBY) and commercial bulb yield (CBY) of conventional or virus-free plants grown from large clove-seeds were higher than those of plants grown from small clove-seeds, except conventional plants grown in the spacing of $12.5 \mathrm{~cm}$, in which the clove-seed sizes had no effect on the TBY and CBY (Table 3). These higher TBY and CBY were due to the increase in mean bulb weight. The use of large clove-seeds resulted in higher MBW due to the higher vegetative growth (height) of the garlic plants, since the larger the leaf area, the greater the interception of radiation and, consequently, the net photosynthesis, resulting in higher dry matter accumulation (CASTELLANOS et al., 2004; AHMED et al., 2017). 
A. $\quad \longrightarrow(\mathrm{VF}-\mathrm{S}) \mathrm{Y}=14.98+11.68 /(1+\exp (-(\mathrm{X}-9.52) / 1.09)) \mathrm{R}^{2}=0.95$ *

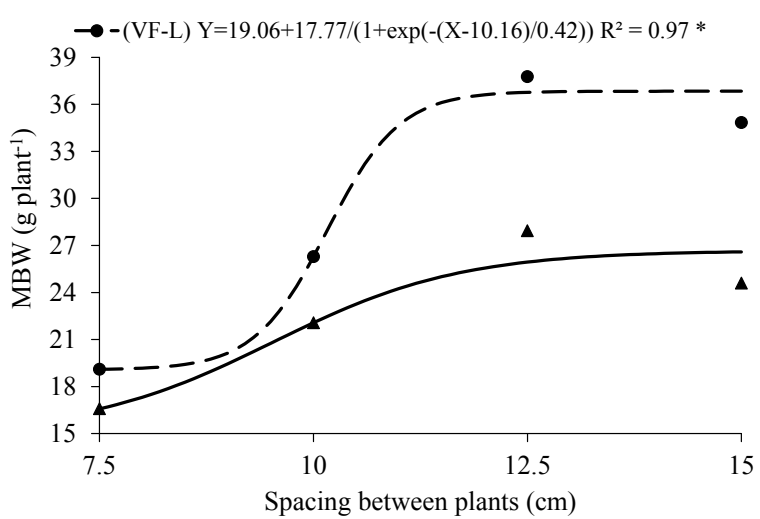

B. $\quad-(\mathrm{CON}-\mathrm{S}) \mathrm{Y}=12.33+5.37 /(1+\exp (-(\mathrm{x}-9.03) / 1.35)) \mathrm{R}^{2}=0.96 * *$

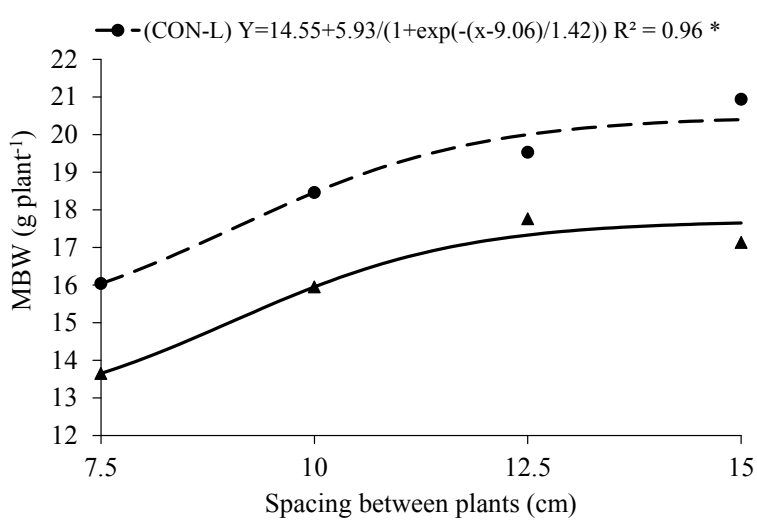

Figure 2. Mean bulb weight (MBW) of virus-free (VF) (A) and conventional (CON) (B) garlic plants grown from small (S) and large (L) clove-seeds under different spacings between plants.

Table 3. Mean total and commercial garlic bulb yields of conventional and virus-free plants grown from small and large clove-seed sizes under different spacings between plants.

\begin{tabular}{|c|c|c|c|c|c|}
\hline \multirow{3}{*}{$\begin{array}{l}\text { Spacing between } \\
\text { plants }(\mathrm{cm})\end{array}$} & \multirow{3}{*}{ Plant health } & \multicolumn{2}{|c|}{$\begin{array}{l}\text { Total yield } \\
\left(\mathrm{Mg} \mathrm{ha}^{-1}\right)\end{array}$} & \multicolumn{2}{|c|}{$\begin{array}{l}\text { Commercial yield } \\
\left(\mathrm{Mg} \mathrm{ha}^{-1}\right)\end{array}$} \\
\hline & & \multicolumn{2}{|c|}{ Clove-seed size } & \multicolumn{2}{|c|}{ Clove-seed size } \\
\hline & & Small & Large & Small & Large \\
\hline \multirow{2}{*}{7.5} & Conventional & $5.88 \mathrm{Bb}$ & $6.98 \mathrm{Ab}$ & $4.60 \mathrm{Bb}$ & $5.99 \mathrm{Ab}$ \\
\hline & Virus-free & $7.95 \mathrm{Ba}$ & $9.01 \mathrm{Aa}$ & $6.96 \mathrm{Ba}$ & $8.46 \mathrm{Aa}$ \\
\hline \multirow{2}{*}{10} & Conventional & $5.24 \mathrm{Bb}$ & $6.08 \mathrm{Ab}$ & $4.30 \mathrm{Bb}$ & $5.57 \mathrm{Ab}$ \\
\hline & Virus-free & $8.03 \mathrm{Ba}$ & $9.38 \mathrm{Aa}$ & $8.00 \mathrm{Ba}$ & $9.38 \mathrm{Aa}$ \\
\hline \multirow{2}{*}{12.5} & Conventional & $4.47 \mathrm{Ab}$ & $5.02 \mathrm{Ab}$ & $3.73 \mathrm{Ab}$ & $4.35 \mathrm{Ab}$ \\
\hline & Virus-free & $7.87 \mathrm{Ba}$ & $11.0 \mathrm{Aa}$ & $7.85 \mathrm{Ba}$ & $11.0 \mathrm{Aa}$ \\
\hline \multirow{2}{*}{15} & Conventional & $3.69 \mathrm{Bb}$ & $4.59 \mathrm{Ab}$ & $2.95 \mathrm{Bb}$ & $4.05 \mathrm{Ab}$ \\
\hline & Virus-free & $5.81 \mathrm{Ba}$ & $8.67 \mathrm{Aa}$ & $5.76 \mathrm{Ba}$ & $8.67 \mathrm{Aa}$ \\
\hline
\end{tabular}

Means followed by same uppercase letter in the rows comparing the clove sizes within each plant health and spacing between plants, and lowercase letter in the columns comparing plant health within each clove-seed size and spacing between plants, are not different by the t Student test $(p \leq 0.05)$.

These results are consistent with those found in other studies, which report higher garlic yields when using large clove-seeds. Gautam et al. (2014) found garlic bulb production $78 \%$ higher for cloveseeds of 1.6-2 $\mathrm{g}$ when compared to clove-seeds of 1-1.5 g; however, the use of clove-seeds of $3.1 \mathrm{~g} \mathrm{did}$ not show significantly higher bulb production. Nasir, Regasa and Yirgu (2017) found 20\% higher TBY and $24 \%$ higher CBY when using garlic clove-seeds of 2.6-3.5 g, when compared to the use of cloveseeds of $1.5-2.5 \mathrm{~g}$.

Therefore, the clove-seed size is important for garlic crops, mainly during the initial crop stages, since, the nutrient reserves in the clove-seeds are partially responsible to supply the plant needs and are essential during and after the emergence, and result in higher bulb yields.

Considering the effect of the plant health within each clove-seed size and spacing between plants on the TBY and CBY, virus-free plants were superior to conventional ones (Table 3). Virus-free plants of small and large clove-seed sizes had 54\% and $68 \%$, higher mean $\mathrm{TBY}$, and $83 \%$ and $87 \%$ higher CBY, respectively, than conventional plants.

Virus-free plants had, in general, higher vegetative growth and, consequently, higher MBW, which explains the higher TBY and CBY when compared to conventional plants. Ahmed et al. (2017) report that garlic bulb production is related to the plant vegetative development, and higher plants present higher bulb production potential due to the highest translocation of nutrients and photoassimilates from leaves and stems to bulbs. In addition, the presence of viruses in garlic plants usually decreases the growth index (height), number of leaves, and leaf area, probably due to metabolic disturbances, mainly photosynthesis inhibition, which affects the synthesis and transport of 
assimilates, and the action of plant growth regulators (VICENTE, 1979).

Similar results were found by Resende, Gualberto and Souza (2000), who evaluated four conventional and virus-free cultivars and found that plants from virus-free clove-seeds were superior to conventional ones in all production characteristics, with $46 \%$ and $63 \%$ higher mean TBY and CBY, respectively. Other studies have also reported higher productive performances for plants from virus-free clove-seeds when compared to conventional plants, with 39\% (MARODIN, 2014) and 84\% (RESENDE; FAQUIN; SOUZA, 2000) higher yields.

TBY and CBY of plants from virus-free seeds showed different responses to the spacing between plants within each clove-seed size. The TBY and $\mathrm{CBY}$ of plants from small clove-seeds increased as the spacing between plants was increased, reaching 8.22 and $8.16 \mathrm{Mg} \mathrm{ha}^{-1}$ in the spacing of 10.0 and $10.5 \mathrm{~cm}$, respectively, but had a subsequent decrease, reaching 5.9 and $5.8 \mathrm{Mg} \mathrm{ha}^{-1}$, respectively in the spacing of $15.0 \mathrm{~cm}$. The TBY and CBY of plants from large clove-seeds increased as the spacing between plants was increased, reaching 11.09 and $11.07 \mathrm{Mg} \mathrm{ha}$ in the spacing of $12.5 \mathrm{~cm}$, respectively, but had a subsequent decrease, reaching $8.74 \mathrm{Mg} \mathrm{ha}^{-1}$ in the spacing of $15.0 \mathrm{~cm}$ (Figure 3A and $3 \mathrm{C}$ ).

The use of low spacings between plants usually results in high mean garlic yields mainly due to the high number of bulbs per unit of area. However, despite the lowest spacings between plants used $(7.5$ and $10 \mathrm{~cm})$ for large clove-seeds resulted in a higher competition between the plants, lowering the total bulb weight, the high MBW in the spacing of $12.5 \mathrm{~cm}$ compensated the low plant population, resulting in a higher TBY and CBY. Moreover, no significantly higher MBW was found for the spacing of $15 \mathrm{~cm}$; thus, the use of low plant densities results in low TBY and CBY (MENGESHA; TESFAYE, 2015; VIDYA, 2015).

The use of large virus-free clove-seeds did not compensate the decrease in plant population when using spacings of $10 \mathrm{~cm}$ or higher, resulting in lower TBY and CBY. Thus, the spacing of $10 \mathrm{~cm}$ between plants result in the highest bulb yields when using small clove-seeds.

Pereira et al. (2009) evaluated plants of the Gigante Roxo garlic cultivar grown from conventional clove-seeds and found that increasing the spacing between plants from 8 to $12 \mathrm{~cm}$ increases the bulb yield in up to $15 \%$; spacings between plants of 10 and $12 \mathrm{~cm}$ are those used by high-technology production systems in Brazil. Contrastingly, Marodin (2014) evaluated garlic plants grown under spacings of 210, 260, 300, 360 and $390 \mathrm{~cm}^{2}$ plant $^{-1}$, in Lavras, state of Minas Geraais, Brazil, and found a linear decrease as the plant spacing was increased for virusfree (Chonan cultivar) and conventional plants.

The TBY of conventional plants decreased as the spacing between plants was increased, for both clove-seed sizes; the highest estimated TBY (5.89 and $6.79 \mathrm{Mg} \mathrm{ha}^{-1}$ ) was found for the spacing of 7.5 $\mathrm{cm}$, and the lowest (3.68 and 4.26 $\mathrm{Mg} \mathrm{ha}^{-1}$ ) for the spacing of $15.0 \mathrm{~cm}$, when using small and large clove-seeds, respectively (Figure 3B).

The CBY of conventional plants grown from small and large clove-seeds was affected by the spacing between plants, with similar effect to that on the TBY; the CBY decreased as the spacing between plants was increased. The use of small and large clove-seeds resulted in the highest commercial yield, 4.60 and $5.99 \mathrm{Mg} \mathrm{ha}^{-1}$, respectively, in the spacing of $7.5 \mathrm{~cm}$, which was lower when using the spacing of $15.0 \mathrm{~cm}$ between plants (Figure 3D).

The conventional garlic plants had lower vegetative growth, thus, the higher $\mathrm{MBW}$ in the spacing of $7.5 \mathrm{~cm}$ was not enough to compensate the low plant density. Therefore, regardless of the cloveseed size used, the highest yield found for high populational density can be attributed to the compensatory effect of the number of plants per unit of area on individual performance of the plants (VIDYA, 2015).

These results are consistent with those found by Ahmed et al. (2017), who evaluated conventional plants of the China cultivar in Pakistan and found the highest bulb production for the spacing of $10 \mathrm{~cm}$ between plants, and the lowest for the spacing of 20 $\mathrm{cm}$. Olfati, Najafabadi and Rabiee (2016) evaluated three spacings between rows $(15,25$, and $35 \mathrm{~cm})$ and found that the lowest spacing resulted in $78 \%$ higher TBY when compared to the highest. Mengesha and Tesfaye (2015) evaluated three spacings between plants $(10,15$, and $20 \mathrm{~cm})$ with $30 \mathrm{~cm}$ between rows and found $38 \%$ higher yield for the spacing of $20 \mathrm{~cm}$ $\left(7.87 \mathrm{Mg} \mathrm{ha}^{-1}\right)$, when compared to the spacing of 10 $\mathrm{cm}\left(4.85 \mathrm{Mg} \mathrm{ha}^{-1}\right)$.

The combination of virus-free garlic, large clove-seeds, and spacing of $7.5 \mathrm{~cm}$ between plants presented the lowest total operational cost (Table 4). This is due to the labor costs and the clove-seed cost, since the price of large virus-free garlic clove-seeds is higher, and the need for a higher quantity of cloveseeds (500.000 clove-seeds ha $\left.{ }^{-1}\right)$. 

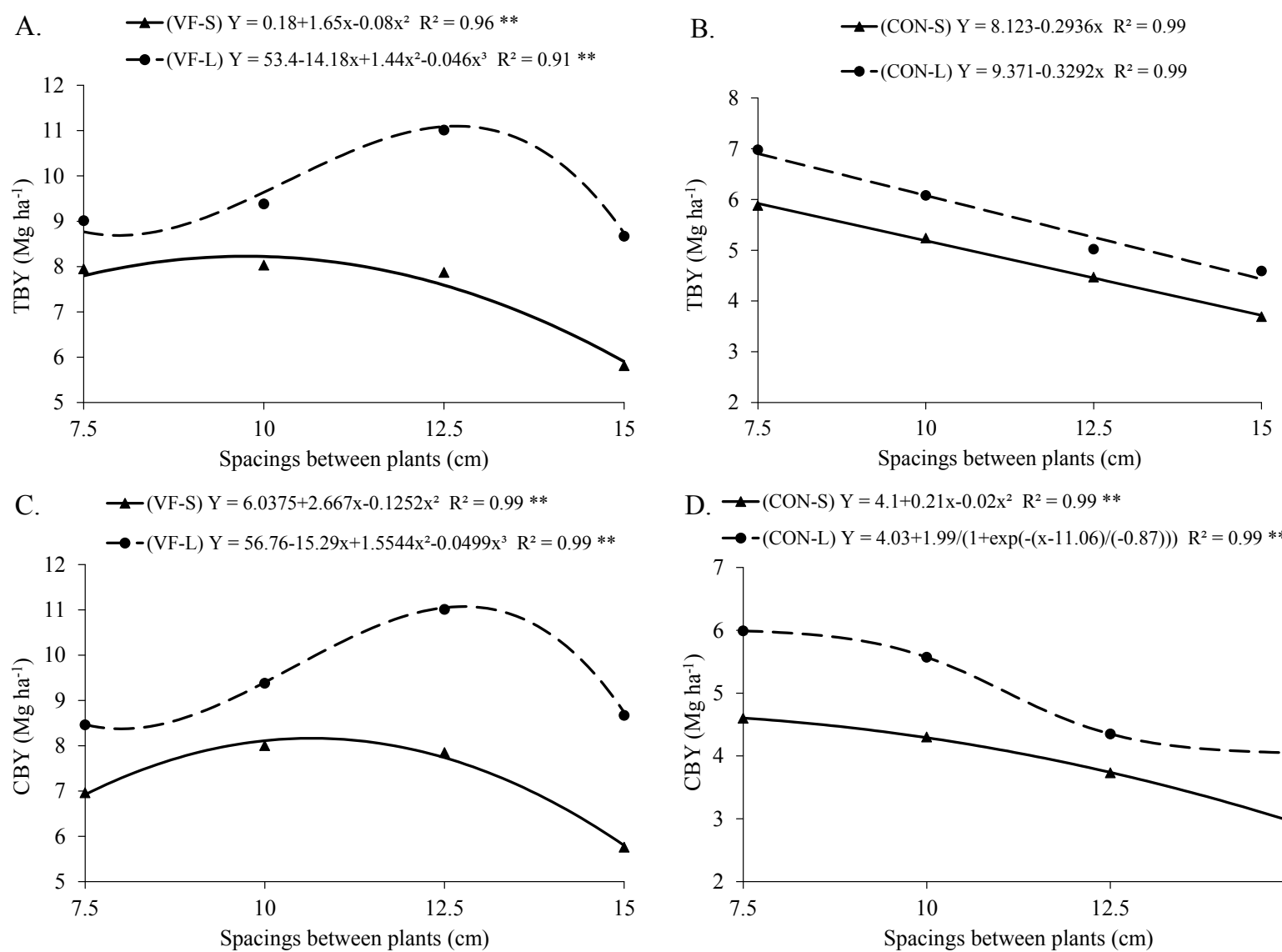

$\begin{aligned} & \text { D. } \rightarrow(\mathrm{CON}-\mathrm{S}) \mathrm{Y}=4.1+0.21 \mathrm{x}-0.02 \mathrm{x}^{2} \mathrm{R}^{2}=0.99 * * \\ & \rightarrow-(\mathrm{CON}-\mathrm{L}) \mathrm{Y}=4.03+1.99 /(1+\exp (-(\mathrm{x}-11.06) /(-0.87))) \mathrm{R}^{2}=0.99 * *\end{aligned}$

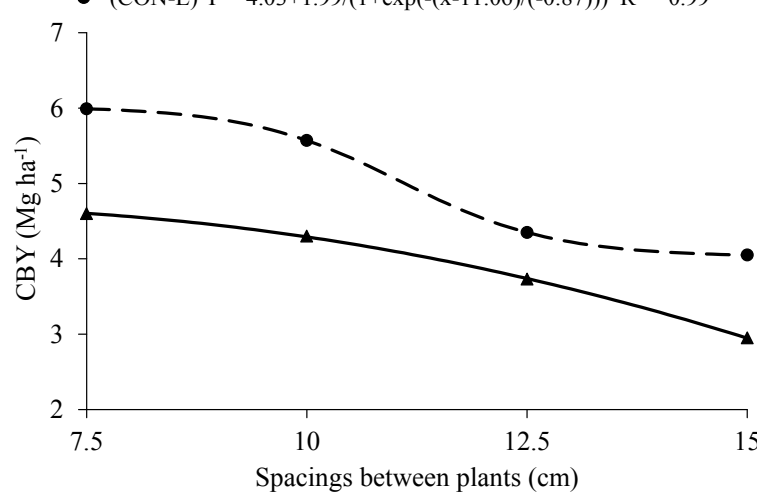

E. $\quad$ - $\mathrm{Y}(\mathrm{GI}-\mathrm{VFS})=31513.38+802.59 \mathrm{x}^{2}-3.005 \mathrm{x}^{4} \mathrm{R}^{2}=0.99 * *$

$\rightarrow \mathrm{Y}(\mathrm{GI}-\mathrm{VFL})=\left(1.7 \cdot 10^{-5}-1.2 \cdot 10^{-7} \mathrm{x}^{2} \ln \mathrm{x}+1.9 \cdot 10^{-8} \mathrm{X}^{3}\right)^{-1} \mathrm{R}^{2}=0.93 * *$

$\cdots \cdot \mathrm{Y}(\mathrm{NI}-\mathrm{VFS})=-17206.69+957.60 \mathrm{x}^{2}-3.345 \mathrm{x}^{4} \mathrm{R}^{2}=0.99 * *$

$\rightarrow-\mathrm{Y}(\mathrm{NI}-\mathrm{VFL})=\left(10.2 \cdot 10^{-5}-1.5 \cdot 10^{-5} \mathrm{x}+5.8 \cdot 10^{-7} \mathrm{x}^{2}\right)^{-1} \mathrm{R}^{2}=0.96 * *$

F.

- $-\mathrm{Y}(\mathrm{GI}-\mathrm{CONS})=48079.9606-56.9249 \mathrm{x}^{2} \mathrm{R}^{2}=0.86$ *

$\rightarrow \mathrm{Y}(\mathrm{GI}-\mathrm{CONL})=74437-1997.9 \mathrm{x} \mathrm{R}^{2}=0.98 * *$

$\cdots \bullet \mathrm{Y}(\mathrm{NI}-\mathrm{CONS})=10221.35+27.15 \mathrm{x}^{2}-0.002708 \exp (\mathrm{x}) \mathrm{R}^{2}=0.99 * *$

$\rightarrow-\mathrm{Y}(\mathrm{NI}-\mathrm{CONL})=\left(5.7 \cdot 10^{-5}-5 \cdot 10^{-6} \mathrm{X}+3.4 \cdot 10^{-7} \mathrm{x}^{2}\right)^{-1} \quad \mathrm{R}^{2}=0.95 * *$
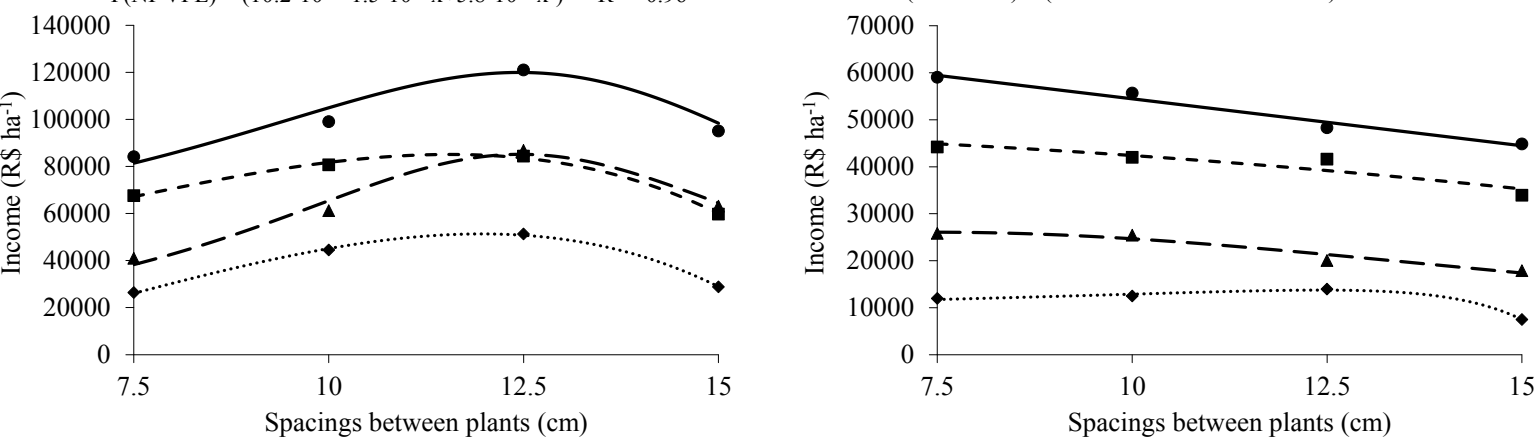

Figure 3. Total bulb yield (TBY) of virus-free (VF) (A), and conventional (CON) (B) garlic plants; commercial bulb yield (CBY) of VF (C), and CON (D) garlic plants; gross and net income of VF (E) and CON (F) garlic plants grown from small (S) and large (L) clove-seed sizes under different spacings between plants.

The use of large clove-seeds resulted in a higher gross and net income for conventional and virus-free crops than the use of small clove-seeds. Considering the differences in plant health within each clove-seed size and spacing between plants, the gross and net income from garlic bulbs from virusfree plants were superior than those from conventional ones (Table 5). The difference in net income between health and conventional plants ranged from $\mathrm{R} \$$ (BRL) 14,391.74 to $\mathrm{R} \$$ (BRL) $66,739.97$, and the difference in net income between clove sizes ranged from $\mathrm{R} \$(\mathrm{BRL}) 6,076.87$ and $\mathrm{R} \$$ (BRL) 35,476.64 ha ${ }^{-1}$.

Despite the use of virus-free seeds and large clove-seeds had a mean total operational cost $22 \%$ and 4\% higher (Table 4), respectively, when compared to the use of conventional and small clove -seeds, the higher yields of these superior seeds compensated the increases in costs.

Castellanos et al. (2004) found higher production costs when using large clove-seeds (10 $\mathrm{g}$ clove-seed $^{-1}$ ), but higher gross income (US\$ 
$25,335.00 \mathrm{ha}^{-1}$ ). However, the highest profit (US\$ $13,461.00)$ was obtained when using seeds of 3.6 and $6.5 \mathrm{~g} \mathrm{clove-seed}^{-1}$, since the use of larger seeds require higher quantities of seeds, which increases production costs; thus, despite obtaining the highest gross income, the net income is lower.

The gross and net income was affected by the spacing between plants; they increased as the spacing between plants was increased, reaching the estimates of R\$ (BRL) 119,958.00 and R\$ (BRL) $85,151.00 \mathrm{ha}^{-1}$, respectively, when using virus-free plants grown from large clove-seeds under the spacing of $12.5 \mathrm{~cm}$. The gross and net income also increased as the spacing between plants was increased up to the spacing of $12.0 \mathrm{~cm}$ when using small clove-seeds, reaching the estimates of $\mathrm{R} \$$ (BRL) 85,100.00 and R\$ (BRL) 51,322.00 ha ${ }^{-1}$ (Figure 3E).

Table 4. Total operational cost of conventional and virus-free garlic crops grown from small and large clove-seed sizes (CSS) under different spacings between plants (SBP).

\begin{tabular}{|c|c|c|c|c|c|c|c|}
\hline \multicolumn{8}{|c|}{ Total operational cost (TOC) } \\
\hline \multirow{2}{*}{ Plant health } & \multirow{2}{*}{ CSS } & \multirow{2}{*}{ SBP } & \multicolumn{5}{|c|}{ Costs in $\mathrm{R} \$(\mathrm{BRL}) \mathrm{ha}^{-1}$} \\
\hline & & & Inputs* & Fertilizers & Labor & Seeds & TOC \\
\hline \multirow{8}{*}{ Virus-free } & \multirow{4}{*}{ Small } & 7.5 & 9726.20 & 5676.50 & 7824.00 & 18000.00 & 41226.70 \\
\hline & & 10 & 9726.20 & 5676.50 & 7352.70 & 13500.00 & 36255.40 \\
\hline & & 12.5 & 9726.20 & 5676.50 & 6881.50 & 10800.00 & 33084.20 \\
\hline & & 15 & 9726.20 & 5676.50 & 6567.40 & 9000.00 & 30970.10 \\
\hline & \multirow{4}{*}{ Large } & 7.5 & 9726.20 & 5676.50 & 7824.00 & 20000.00 & 43226.70 \\
\hline & & 10 & 9726.20 & 5676.50 & 7352.70 & 15000.00 & 37755.40 \\
\hline & & 12.5 & 9726.20 & 5676.50 & 6881.50 & 12000.00 & 34284.20 \\
\hline & & 15 & 9726.20 & 5676.50 & 6567.40 & 10000.00 & 31970.10 \\
\hline \multirow{8}{*}{ Conventional } & \multirow{4}{*}{ Small } & 7.5 & 9726.20 & 5676.50 & 7824.00 & 9000.00 & 32226.70 \\
\hline & & 10 & 9726.20 & 5676.50 & 7352.70 & 6750.00 & 29505.40 \\
\hline & & 12.5 & 9726.20 & 5676.50 & 6881.50 & 5400.00 & 27684.20 \\
\hline & & 15 & 9726.20 & 5676.50 & 6567.40 & 4500.00 & 26470.10 \\
\hline & \multirow{4}{*}{ Large } & 7.5 & 9726.20 & 5676.50 & 7824.00 & 10000.00 & 33226.70 \\
\hline & & 10 & 9726.20 & 5676.50 & 7352.70 & 7500.00 & 30255.40 \\
\hline & & 12.5 & 9726.20 & 5676.50 & 6881.50 & 6000.00 & 28284.20 \\
\hline & & 15 & 9726.20 & 5676.50 & 6567.40 & 5000.00 & 26970.10 \\
\hline
\end{tabular}

*Inputs include irrigation equipment, agrochemicals, and electrical energy.

Table 5. Mean gross and net income of conventional and virus-free plants grown from small and large clove-seed sizes under different spacings between plants (SBP).

\begin{tabular}{|c|c|c|c|c|c|}
\hline \multirow{3}{*}{$\begin{array}{l}\text { SBP } \\
(\mathrm{cm})\end{array}$} & \multirow{3}{*}{ Plant health } & \multicolumn{2}{|c|}{$\begin{array}{l}\text { Gross income } \\
\text { R\$ (BRL) ha }{ }^{-1}\end{array}$} & \multicolumn{2}{|c|}{$\begin{array}{c}\text { Net income } \\
\text { R\$ (BRL) ha }{ }^{-1}\end{array}$} \\
\hline & & \multicolumn{2}{|c|}{ Clove-seed size } & \multicolumn{2}{|c|}{ Clove-seed size } \\
\hline & & Small & Large & Small & Large \\
\hline \multirow{2}{*}{7.5} & Conventional & $44,184.81 \mathrm{Bb}$ & $59,042.26 \mathrm{Ab}$ & $44,184.81 \mathrm{Bb}$ & $59,042.26 \mathrm{Ab}$ \\
\hline & Virus-free & $67,576.55 \mathrm{Ba}$ & $84,135.69 \mathrm{Aa}$ & $67,576.55 \mathrm{Ba}$ & $84,135.69 \mathrm{Aa}$ \\
\hline \multirow{2}{*}{10} & Conventional & $41,985.00 \mathrm{Bb}$ & $55,660.08 \mathrm{Ab}$ & $41,985.00 \mathrm{Bb}$ & $55,660.08 \mathrm{Ab}$ \\
\hline & Virus-free & $80,694.73 \mathrm{Ba}$ & $98,982.25 \mathrm{Aa}$ & $80,694.73 \mathrm{Ba}$ & $98,982.25 \mathrm{Aa}$ \\
\hline \multirow{2}{*}{12.5} & Conventional & $41,618.50 \mathrm{Bb}$ & $48,295.37 \mathrm{Ab}$ & $41,618.50 \mathrm{Bb}$ & $48,295.37 \mathrm{Ab}$ \\
\hline & Virus-free & $84,358.70 \mathrm{Ba}$ & $121,035.34 \mathrm{Aa}$ & $84,358.70 \mathrm{Ba}$ & $121,035.34 \mathrm{Aa}$ \\
\hline \multirow{2}{*}{15} & Conventional & $33,934.38 \mathrm{Bb}$ & $44,848.35 \mathrm{Ab}$ & $33,934.38 \mathrm{Bb}$ & $44,848.35 \mathrm{Ab}$ \\
\hline & Virus-free & $59,730.72 \mathrm{Ba}$ & $95,089.79 \mathrm{Aa}$ & $59,730.72 \mathrm{Ba}$ & $95,089.79 \mathrm{Aa}$ \\
\hline
\end{tabular}

Means followed by same uppercase letter in the rows comparing the clove sizes within each plant health and spacing between plants, and lowercase letter in the columns comparing plant health within each clove-seed size and spacing between plants, are not different by the t Student test $(p \leq 0.05)$.

However, conventional plants had different dynamics; the gross and net income was affected by the spacings between plants, but with decreases as the spacing between plants was increased when using large clove-seeds under the spacing of $7.5 \mathrm{~cm}$, reaching the estimates of $\mathrm{R} \$(\mathrm{BRL}) 58,832.00$ and R\$ (BRL) 25,815.00 $\mathrm{ha}^{-1}$, respectively. Moreover, the gross income decreased as the spacing between 
plants was increased when using small clove-seeds under the spacing of $7.5 \mathrm{~cm}$, reaching the estimates of $\mathrm{R} \$$ (BRL) 44,887.00. However, the net income had a slight increase for spacings higher than 7.5 , reaching the estimate of $\mathrm{R} \$(\mathrm{BRL}) 11,743.00$ in the spacing of $12.5 \mathrm{~cm}$ (Figure 3F).

The garlic crops presented favorable results for several economic efficiency indexes. The spacings that resulted in the highest total and commercial yields provided, in general, the highest profits. Thus, the combination of virus-free seeds, large clove-seeds, and spacings between plants of $12.5 \mathrm{~cm}$ (300000 plants $\left.\mathrm{ha}^{-1}\right)$ was the treatment with higher commercial yield $\left(11 \mathrm{Mg} \mathrm{ha}^{-1}\right)$ and provided the highest net income, R\$ (BRL) 85,151.00 ha ${ }^{-1}$.

These results were consistent with those found by of Castellanos et al. (2004), who found that the density of 600000 plants $\mathrm{ha}^{-1}$ resulted in the highest yields and production cost, but provided a profitability $15 \%$ lower than the use of a populational density of 300000 plants $\mathrm{ha}^{-1}$. This is due to the production of large bulbs, i.e., with higher market value, which compensate the low yield of low populational density, and the increase in production cost of crops with higher densities, due to higher cost with seeds.

Therefore, the garlic crops were profitable when considering the costs involved and the economic return. Moreover, the use of virus-free garlic plants for commercial production should be monitored; despite these virus-free seeds have a high productive potential and economic return, they can undergo degeneration and cause decrease in the production when not managed correctly, mainly in successive crops.

\section{CONCLUSIONS}

The garlic crops grown using virus-free clove -seeds and large clove-seeds presented the highest vegetative growth, yield, and economic return.

The combination of virus-free clove-seeds, large clove-seeds, and spacing between plants of $12.5 \mathrm{~cm}$ resulted in the highest net income, $\mathrm{R} \$$ (BRL) 85,151.00 ha- ${ }^{-1}$.

The use of large clove-seeds with spacing between plants of $7.5 \mathrm{~cm}$ is recommended for the growth of conventional garlic plants.

\section{ACKNOWLEDGEMENTS}

This study was conducted with the support of the Brazilian Coordination for the Improvement of Higher Education Personnel (CAPES; Financing Code 001).

\section{REFERÊNCIAS}

AHMED, I. et al. Impact of plant spacing on garlic rust (puccinia allii), bulb yield and yield component of garlic (Allium sativum). Pakistan Journal of Agricultural Research, 30: 380-385, 2017.

CASTELLANOS, J. Z. et al. Garlic productivity and profitability as affected by seed clove size, planting density and planting method. HortScience, 39: 1272 $-1277,2004$.

EMBRAPA - Empresa Brasileira de Pesquisa Agropecuária. Sistema brasileiro de classificação de solos. Brasília, DF: Embrapa, 2018. 590 p.

GAUTAM, N. et al. Growth and yield of garlic (Allium sativum L.) as influenced by clove weight and plant growth regulators. International Journal of Farm Sciences, 4: 49-57, 2014.

IBGE - Instituto Brasileiro de Geografia e Estatística. Levantamento Sistemático da Produção Agrícola. Disponível em: <https:// cidades.ibge.gov.br/brasil/pesquisa/panorama> . Acesso em: 08 nov. 2017.

LENCHA, B.; BUKE, T. Effects of clove size and plant density on the bulb yield and yield components of garlic (Allium sativum L.) in Sodo Zuria Woreda, southern wolaita zone. Journal of Natural Sciences Research, 7: 1-7, 2017.

LIMA, M. F. P. et al. Garlic quality as a function of seed clove health and size and spacing between plants. Revista Caatinga, 32: 966-975, 2019.

LUÍS, M. A. S. et al. Organic mulch on early garlic cultivars grown under semiarid conditions. Revista Caatinga, 33, 412-421, 2020.

MARODIN, J. C. Produtividade de alho em função da sanidade e tamanho do alho semente e da densidade de plantio. 2014. $97 \mathrm{f}$. Tese (Doutorado em Fitotecnia: Área de Concentração em Produção Vegetal) - Universidade Federal de Lavras, Lavras, 2014.

MAHADEEN, A. Y. Influence of clove weight on vegetative growth and yield of garlic (Allium sativum L.) grown under drip irrigation. Jordan Journal of Agricultural Sciences, 7: 44-50, 2011.

MARTIN, N. B. et al. Sistema integrado de custos agropecuários - CUSTAGRI. São Paulo, SP: IEA, 1998. $22 \mathrm{p}$. 
MELO FILHO, P. A. et al. Viral reinfection affecting bulb production in garlic after seven years of cultivation under field conditions. European Journal of Plant Pathology, 116: 95-101, 2006.

MENEZES JÚNIOR, F. O. G. Cultivo in vitro do alho visando a limpeza clonal. Revista de Ciências Agroveterinárias, 10: 158-167, 2011.

MENGESHA, W.; TESFAYE, A. Effect of spacing in incidence and severity of garlic rust (Puccinia allii) and bulb yield and related traits of garlic at eastern Ethiopia. Plant Pathology and Microbiology, 6: 314-317, 2015.

MORAVČEVIĆ, D. et al. Effect of plant density on the characteristics of photosynthetic apparatus of garlic (Allium sativum var. vulgare L.). African Journal of Biotechnology, 10: 15861-15868, 2011.

MUNEER, N. et al. Effect of planting density on growth, yield and quality of Garlic at Rawalakot, Azad Kashmir. International Journal of Agronomy and Agricultural Research, 10: 42-51, 2017.

NASIR, S.; REGASA, T.; YIRGU, M. Influence of clove weight and planting depth on yield and yield components of garlic (Allium sativum L.). American

-Eurasian Journal of Agricultural e Environmental Sciences, 17: 315-319, 2017.

OLFATI, J.; NAJAFABADI, M. M.; RABIEE M. Between-row spacing and local accession on the yield and quality of garlic. Comunicata Scientiae, 7: 112-121, 2016.

PEREIRA, W. R. et al. Estudo da densidade de plantio em alho na região de Inconfidentes/MG. Revista Agroambiental, 1: 43-50, 2009.

RESENDE, F. V.; FAQUIN, V.; SOUZA, R. J. Efeito da adubação nitrogenada no crescimento e na produção de alho proveniente de cultura de tecidos e de multiplicação convencional. Revista Brasileira Ciência do Solo, 24: 49-57, 2000.

RESENDE, F. V.; GUALBERTO, R.; SOUZA, R. J. Crescimento e produção de clones de alho provenientes de cultura de tecidos e de propagação convencional. Scientia Agricola, 57, 61-66, 2000.

RESENDE, F. V. et al. Comparação do crescimento e produção entre alho proveniente de cultura de tecidos e de multiplicação convencional. Horticultura Brasileira, 17: 118-124, 1999. vernalizado proveniente de cultura de meristemas cultivado sob doses de nitrogênio. Horticultura Brasileira, 29: 498-503, 2011.

VICENTE, M. Fisiologia de plantas infectadas por vírus. Fitopatologia Brasileira, 4: 181-187, 1979.

VIDYA, G. Effect of planting time and plant densities on yield and yield contributing characters in garlic (Allium sativum L.) Cv. Jamnagar. Plant Archives, 15: 947-952, 2015.

SOUZA, R. J. et al. Absorção de nutrientes em alho 